\title{
Spatial Analysis of Mangrove Forest Management for the Reduction of Air Temperature and $\mathrm{Co} 2$ Emission
}

Sumarmi - ( $\nabla$ sumarmi.fis@um.ac.id )

Universitas Negeri Malang

Purwanto -

Universitas Negeri Malang

Tuti Mutia

Sekolah Tinggi Keguruan dan Ilmu Pendidikan Hamzanwadi

\section{Research}

Keywords: Spatial Analysis, Mangrove Forest, CO2 Emission

Posted Date: June 4th, 2020

DOI: https://doi.org/10.21203/rs.3.rs-30308/v1

License: (c) (1) This work is licensed under a Creative Commons Attribution 4.0 International License. Read Full License 


\section{Abstract}

Surabaya is one of the developing cities in term of coastal area. Like other developing cities, Surabaya highlysuppresses the mangrove forest for the residential area, industry and so forth. Mangrove forest as a conservation land has an essential function as an oxygen source for people in Surabaya and it absorbs $\mathrm{CO}_{2}$. Mangrove forest functions to decrease the impact of global warming and maintain the coastal ecosystem sustainability. This research aimed to 1) Map the dynamics of temperature in Surabaya during the last twenty years (1996-2016) by using Remote Sensing and GIS. 2) Examine the ability of mangrove forest in absorbing $\mathrm{CO}_{2}$ and heat energy in decreasing the impact of global warming in Surabaya. The research results showed that 1) based on the analysis result of temperature surface extent, the temperature has changed since 1996 up to 2016. The trend of the temperature change can be classified into three surface temperatures which are low, moderate and high. The low temperature with the category of $21^{\circ}-30^{\circ} \mathrm{C}$ had a differenttrend. Every year, the trend of the area extent of which surface temperature was highly categorized was $31-42^{\circ} \mathrm{C}$. The trend was highly increasing in the period of 2006-2016. Such condition showed that, in 2016, Surabaya had a high temperature increase. (2) There was a correlation between mangrove forest change and the temperature change; the content of $\mathrm{CO}_{2}$ in the mangrove, vegetation and water areas was reduced and it increased in the areas used for buildings such as factory, residential, road and so on. The content of $\mathrm{CO}_{2}$ in the air of Surabaya showed the distribution grouping in the "high" and "extremely high" categories. The highcategory was $27.5 \%$ and the extremely high category was $67.5 \%$. There was one sample point in each of moderate and low categories which was $2.5 \%$ respectively.

\section{Background}

Some cities in Indonesia have a higher average value of surface temperature compared with their surrounding areas due to the high urban physical development. Such physical development includes: commercial, governmental, residential, industrial buildings, and so forth. In the contrary, the chart of vegetation zones showed that vegetation zones such as paddy fields, plantations, or forest conservation areas are in decline [1].

There was a similar condition in Surabaya where an increasing temperature since 1994 to 2012 was reported. According to Bryan, 2013, the successive average temperatures recorded from 1994 until 2002 were $28.95^{\circ} \mathrm{C}, 27.07^{\circ} \mathrm{C}, 32.54^{\circ} \mathrm{C}$ and $38.23^{\circ} \mathrm{C}$. The recorded temperature of 2006 and 2009 also increased, namely from $43.06{ }^{\circ} \mathrm{C}$ became $44.30^{\circ} \mathrm{C}$. However, the temperature recorded in 2012 declined to be $34.81^{\circ} \mathrm{C}$. When the $\mathrm{CO}_{2}$ concentration in the atmosphere reaches above $450 \mathrm{ppm}$, then the temperature would increase of more than 2 degree Celsius [2].

The development of the Eastern part of Surabaya for the expansion of Juanda Airport, residential area, and industrial area resulted in mangrove forest preservation became vulnerable. Mangrove forest has a 
key role as a source of oxygen for Surabaya society, and it could absorb sun radiation in declining the impact of global warming.

Mangrove forest contains a higher level of carbon than other kinds of forests on earth [3]. The mangrove ecosystem in Indonesia is able to absorb carbon content in the air of up to $67.7 \mathrm{MtCO}$ per year. Stated that mangroves have a biomass potential of 108.66 and carbon content of 55.35. The high carbon content is influenced by the ability of mangroves to absorb carbon from its surrounds through a photosynthesis process known as the sequestration process [4]. During the photosynthesis process, the $\mathrm{CO}$ generated from the atmosphere will be bound by the vegetation and stored in the form of biomass, so that the CO content in the air will decline [5].

The carbon assimilation ability of mangrove forest is 4 (four) level higher than other tropical forests all around the world [6]. The carbon content of mangroves is the highest in tropical areas, i.e. $1,023 \mathrm{Mg} \mathrm{C} / \mathrm{Ha}$ (above-ground Carbon reserve). The absorbed carbon biomass varies in the age, species, morphology, and location of mangrove [7].

Mangrove forests have a role in reducing the heat caused by climate change, especially through carbon sequestration. Carbon sequestration by mangroves is more unique than that performed by other vegetation. Mangrove forests has an essential role in absorbing atmospheric carbon to control the environmental ecosystem in coastal areas [8]. Plants can emit and absorb unique waves. Therefore, it can relate to waves beamed by other objects so that the vegetation can be distinguished from other objects [9]. The analysis can be done manually or by computer. The LanduseSim technique can be utilized for spatial simulation, including land-use simulation which can accommodate the bottom-up and top-down approaches.

The remote sensing technology, besides forecasting or predicting the future, can present the data and facts of spatial issues happened in the past. Such spatial information can be gathered via spatiotemporal analysis which is superior in showing multi-level, multispectral, multitemporal images with larger spatial extent.

This research aimed (1) to map the dynamics of mangrove area and temperature in Surabaya during the last twenty years (1996-2016) by using Remote Sensing and Geographic Information System, and to examine the ability of mangrove forest in absorbing $\mathrm{CO}_{2}$ and heat energy in decreasing the impact of global warming in Surabaya.

Remote sensing is a science and art to obtain information about an object, area or symptom by analyzing the data recorded by the sensor without the need of a connection with the object, area or symptom [10].. The utilization of remote sensing can be found in various fields of study, namely mapping, agriculture, forestry, natural resource management, urban and regional planning, and other earth science [10], [11].

Landsat is an unmanned earth resources satellite which carries a non-photographic sensor. The most recently launched Landsat satellite on 15 April 1999 was Landsat 7 which carries an Enhanced Thematic 
Mapper Plus (ETM+) sensor (Table 1).

Table 1

Characteristics of Landsat-7 ETM+

\begin{tabular}{|c|c|}
\hline System & Landsat 7 \\
\hline Orbit & $705 \mathrm{~km}, 98.2^{\circ}$, sun synchronous, passes over at $10.00 \mathrm{AM}$, once in 16 days \\
\hline Sensor & ETM+ (Enhanced Thematic Mapper) \\
\hline Coverage & $185 \mathrm{~km}\left(\mathrm{FOV}=15^{\circ}\right)$ \\
\hline Side view & Not available \\
\hline $\begin{array}{l}\text { Temporal } \\
\text { resolution }\end{array}$ & 16 days \\
\hline $\begin{array}{l}\text { Used } \\
\text { wavelength } \\
\text { channels } \\
(\mu \mathrm{m})\end{array}$ & $\begin{array}{l}\text { (Band1) } 0.45-0.52 \mu \mathrm{m},(\text { Band 2) } 0,52-0,60 \mu \mathrm{m}, \text { (Band } 3) 0.63-0.69 \mu \mathrm{m},(\text { Band } 4) \\
0.76-0.90 \mu \mathrm{m},(\text { Band 5) } 1.55-1.75 \mu \mathrm{m},(\text { Band } 6) 10.4-12.50 \mu \mathrm{m},(\text { Band } 7) 2.08- \\
2.34 \mu \mathrm{m},(\text { PAN) } 0.5-0.9 \mu \mathrm{m}\end{array}$ \\
\hline $\begin{array}{l}\text { Spatial } \\
\text { resolution }\end{array}$ & (PAN) $15 \mathrm{~m}$, (band1-5,7) $30 \mathrm{~m}$, dan (Band 6) $60 \mathrm{~m}$ \\
\hline $\begin{array}{l}\text { Data } \\
\text { acquisition }\end{array}$ & Earthexlorer.usgv.gov \\
\hline Source: Lan & t Project Science Office, 2002 \\
\hline
\end{tabular}

\section{Material And Methods}

This research was a survey research designed by using remote sensing and Geographic Information System (SIG). The remote sensing data in the forms of Landsat and Quickbird Satellite images were used to identify temporal changes of mangrove forests and temperature during the last 20 year period. Such data were then integrated with the data resulted from the field measurement, and subsequently analyzed via SIG to identify the mangrove area distribution and temperature pattern in Surabaya. The remote sensing data obtained from Quickbird were used to study the existing land use in relation with the activities of the society around the mangrove area.

The objects of this research were changes occurred specifically in mangrove area in East Surabaya due to global warming. There were several Tools and Materials required in this research. The tools consisted of a computer, ENVI/ErMapper to analyze the Satellite images, SIG Software equipped with ArcGIS 10.2 for the Global Position System (GPS) spatial data analysis, Landusesim 2.2 Software, thermometer to check the field temperature, and a camera. The materials included Indonesia Topographic Map in a scale of 1:25,000, Indonesia Topographic Map in a scale of 1:10,000, Indonesia Bathymetric/coastal environment Map in a scale of 1:50,000, Spatial planning maps of Surabaya and Sidoarjo. Landsat MSS, TM, ETM + and Landsat 8 Satellite images, DEM Aster satellite images, Quickbird satellite images. 
The collected data were categorized into primary and secondary data. The primary data included the data of field temperature, the existing land use, and examination of mangrove forests based on their ability to absorb $\mathrm{CO}_{2}$ and heat energy. The secondary data contained satellite images and maps. The techniques employed for the data collection were survey, interview, and documentation. The survey technique was intended to directly perform a field observation on the study objects, in this case, temperature, land use, and the amount of absorbed $\mathrm{CO}_{2}$ and heat energy. Documentation was performed to collect the data in accordance with the actual spatial use and also as the authentic evidence.

The analysis of changes in mangrove forests was performed by NDVI (Normalized Difference Vegetation Index) method which is a standard method in comparing the level of vegetation of satellite data. The formula of NDVI is as follow:

$N D V I=(N I R-R e d) /(N I R+R e d)$.

The analysis of mangrove ability in absorbing heat energy can be identified from the changes on temperature, especially in the mangrove area located in East Surabaya for the last 20 years. The thermal infrared channels in channel 6 of Landsat TM and ETM + and in channel 10 and 11 in Landsat 8 were used to observe the temperature.

The analyses used to study the influence of changes in land cover on temperature were the Landsat 7 image analysis and a simple linear regression. The results of research obtained from the observation and field measurement were analyzed to be then explained or described. The Landsat 7 image analysis was conducted by converting the imagery data into temperature data. The converted imagery data were the pixel values in band 6 of the Landsat images called as digital number (DN). According to USGS (2003), there are two necessary steps to convert the imagery data into temperature data, namely:

1. A conversion of Digital Number (DN) into spectral Radiance $\left(L_{\lambda}\right)$

Formula: Radiance $\left(L_{\lambda}\right)=($ gain $\times D N)+$ offset

Where:

$L_{\lambda}=$ Spectral Radiance in watt

Gain = a constant of 0.05518

DN (Digital Number) originated from the pixel values of the images

Offset is a constant of 1.2378

b.Spectral Radiance Conversion into Temperature.

The spectral radiance on thermal band image (band 6) could be converted into temperature. The equation of spectral radiance conversion into temperature is: 
$\mathrm{T}=\frac{\mathrm{K} \mathbf{2}}{\ln \left(\frac{\mathrm{K} 1}{\mathrm{~L}+1}\right)}$

Where:

$T=$ Temperature

K1 = Constant in watt with $a$ value of 666.09 ETM+ and 607.76 for TM

K2 = Constant in Kelvin with a value of 1282.71 for ETM+ and 1260.56 for TM

$L=$ Spectral Radiance in watt.

The final result obtained from the equation was in the form of temperature in a Kelvin (K) scale. In order to obtain temperature data in a Celsius $\left({ }^{0} \mathrm{C}\right)$ scale, the equation is changed into:

$$
\mathbf{T}=\left(\frac{K 2}{\ln \left(\frac{K 1}{L_{\lambda}+1}\right)}\right)-\mathbf{2 7 3} \quad T=\text { temperature in Celsius }\left({ }^{\circ} \mathrm{C}\right)
$$

A simple linear regression analysis is done when the types of the variables are free and bound. The changed area of land cover is a free variable $(\mathrm{X})$ while the air temperature is a bound variable $(\mathrm{Y})$. The regression analysis was performed by using SPSS 16 software for Windows.

3. The calculation of Biomass and Carbon of the Mangrove Ecosystem can be performed by the following formula [4]:

Carbon and Biomass Potentials=

$$
\mathrm{ni}=\mathbf{l}=\left(\frac{y i}{\text { plot area }}\right) \mathbf{x} \text { mangrove area }
$$

Where:

Yi= biomass potential per type

$i=$ the $i$ type

4. Spatial Modeling with LanduseSim

The spatial modeling uses landuseSim to predict the changes on land use, temperature, and to determine the scenario of mangrove forest planning.

Results 


\section{Temperature Changes In Surabaya}

The imagery data used in this research were the Landsat 5 TM, Landsat 7 ETM+, and Landsat 8 OLI TIRS satellite images in the format of *.GeoTIFF and contained metadata in the format of *.MTL. The metadata provided information on the image recording time, solar elevation angle, image quality, cloud coverage area, and other important data which were relevant to the images. The imagery data utilized in this research are presented in Table 2.

Table 2

Information of Imagery Data used in the Research

\begin{tabular}{|lllll}
\hline No. & $\begin{array}{l}\text { Name of Satellite } \\
\text { Imageries }\end{array}$ & $\begin{array}{l}\text { Data and Time of } \\
\text { Acquisition }\end{array}$ & $\begin{array}{l}\text { WRS } \\
\text { PATH/ } \\
\text { ROW }\end{array}$ & $\begin{array}{l}\text { Image Quality and Cloud } \\
\text { Coverage }\end{array}$ \\
\hline 1. & LT51180651996211DKI00 & $\begin{array}{l}1996-07-29 / \\
01: 50: 53\end{array}$ & $118 / 65$ & $9 / 3.00$ \\
\hline 2. & LE711180652001264DKI00 & $\begin{array}{l}2001-09-21 / \\
02: 24: 13\end{array}$ & $118 / 65$ & $9 / 10.00$ \\
3. & LE711180652006246EDC00 & $\begin{array}{l}2006-09-03 / \\
02: 25: 23\end{array}$ & $118 / 65$ & $9 / 0.00$ \\
4. & LE711180652011244EDC00 & $118 / 65$ & $9 / 2.00$ \\
5. & LC81180652016090LGN00 & $\begin{array}{l}2011-09-01 / \\
02: 29: 07\end{array}$ & $118 / 65$ & $9 / 25.36$ \\
& & $2016-07-30 /$ & & \\
\hline & & & & \\
\hline
\end{tabular}

Several imagery data that were used in this research were a Landsat Level 1 Standard Data Product. The Level 1 Landsat data were imagery data result from the calibration and validation processes to measure and prevent sensory problems such as the atmospheric condition so that their quality can be improved by using some certain algorithms [20].

The study of surface temperature in Surabaya in the last 2 decades was analyzed through Landsat TM, ETM+, and 8 images. The results of analysis can be seen in Table 3. 
Table 3

Changes on Surface Temperature of Surabaya

\begin{tabular}{|c|c|c|c|c|c|}
\hline \multirow[t]{2}{*}{ Temperature Classes } & \multicolumn{5}{|c|}{ Annual temperature change $\left(\mathrm{km}^{2}\right)$} \\
\hline & 1996 & 2001 & 2006 & 2011 & 2016 \\
\hline Low $\left(11-21^{\circ} \mathrm{C}\right)$ & 0,0657 & 0,4734 & 0,1071 & 5,976 & 9,296 \\
\hline Moderate $\left(22-31^{\circ} \mathrm{C}\right)$ & 334,2231 & 111,4416 & 103,8618 & 323,2089 & 62,0028 \\
\hline $\operatorname{High}\left(32-41^{\circ} \mathrm{C}\right)$ & 0,0054 & 222,3792 & 230,319 & 5,103 & 271,3618 \\
\hline Total Area & 334,2942 & 334,2942 & 334,2879 & 334,2879 & 334,2942 \\
\hline
\end{tabular}

Based on the results of an analysis of surface temperature area, trends of the temperature changes from 1996 until 2016 can be obtained. The trends can be classified into 3 temperature characteristics, i.e. low, moderate, and high. The low temperature comprises of the category of $11-21^{\circ} \mathrm{C}$ having an areadevelopment trend from 1996-2016. It means that Surabaya experienced a positive temperature change for the low temperature category. The trend of temporal changes can be seen in Fig. 1.

The moderate temperature changes with the category of $21^{\circ}-30^{\circ} \mathrm{C}$ showed different trends. The trends of moderate temperature changes are negative trends, which meant that the area with moderate surface temperature was declining annually. The trends of changes are illustrated in Fig. 2.

The trend of moderate temperature changes of $21^{\circ}-30^{\circ} \mathrm{C}$ fluctuated. In early 1996 , the surface temperature still dominated Surabaya which covered an area of $334.2231 \mathrm{Km}^{2}$, but there was a decline from 2001 until 2006. There was an area expansion from 2006 until 2011. However, there was a drastic decrease in 2016 that resulted in the final area of $62.0028 \mathrm{Km}^{2}$.

In other hand, the trend of high surface temperature of $31-42{ }^{\circ} \mathrm{C}$ fluctuated. The fluctuating point of the expansion of area with high surface temperature occurred from 1996-2001, and it declined in 20012006, and then it increases from 2006-2016. Such condition shows that, in 2016, the areas with high temperature in Surabaya kept increasing. The trend of high temperature changes in Surabaya for the last twenty years can be depicted in the following Fig. 3 .

The surface temperature dynamics in Surabaya occurred in a period from 1996-2016 which were due to numerous factors. Some of the dominant factors were the population and their activities. The increasing number of the population went hand in hand with the increasing demand for living place or places for their activities, such as residential area, industrial area, trading site, and so forth. One example of threatened land use by such various activities is the land use for Mangrove forests.

\section{Mangrove Area Changes In Surabaya}


The temperature dynamics closely relate to changes in land function or land use. The land use that became under threat along with the growth of population in Surabaya was the land use for Mangrove Forests. The mangrove forest that functioned as a buffer zone was in a critical condition (Table 4).

Table 4

Trend of Mangrove Area Changes in Surabaya in 1996-2016

\begin{tabular}{|c|c|c|c|c|c|}
\hline \multirow[t]{2}{*}{ No. } & \multicolumn{5}{|c|}{ Changes of Mangrove Area per year $\left(\mathrm{km}^{2}\right)$} \\
\hline & 1996 & 2001 & 2006 & 2011 & 2016 \\
\hline & 1,231 & 3,3039 & 2,872 & 4,484 & 9,459 \\
\hline \multicolumn{6}{|c|}{ Source: Image Processing Results, 2016} \\
\hline
\end{tabular}

The trend of Mangrove area dynamics can be seen from Table 4 above. The mangrove area in 1996 was $1.231 \mathrm{Km}^{2}$, and expanded to $3.3039 \mathrm{Km}^{2}$ in 2001 . However, it declined in 2006 became $2.872 \mathrm{Km}^{2}$ and became $4.484 \mathrm{Km}^{2}$ in 2011 and 9,459 in 2016. The trend of mangrove area changes is depicted in Fig. 4 as follow:

Based on the Fig. 4 above, it can be said that the trend of mangrove area changes from 1996-2016 was increasing. The highest increase occurred in 2016 when the area was $9.4590 \mathrm{Km}^{2}$.

The currently existing mangrove forests can be found in rivers and estuaries or coastal areas. In a hinterland, mangroves grow along the rivers and embankments. Meanwhile, mangroves in estuaries or coastal areas are usually fertile and grow along the riversides. The spatial dynamics of the mangrove area in Wonorejo and the results of the survey are shown in Table 5.

Table 5

Spatial Changes of Mangrove Area

\begin{tabular}{|c|c|c|c|c|c|c|c|c|}
\hline \multirow[t]{2}{*}{ No } & \multirow[t]{2}{*}{ Location } & \multicolumn{2}{|c|}{ Coordinate Point } & \multicolumn{5}{|c|}{$\begin{array}{l}\text { Changes on Vegetation Density (NDVI = } \\
0,1-1)\end{array}$} \\
\hline & & $x$ & $Y$ & 1996 & 2001 & 2006 & 2011 & 2016 \\
\hline 1. & $\begin{array}{l}\text { The main parking area of } \\
\text { Mangrove Ecotourism in } \\
\text { Wonorejo }\end{array}$ & 701500 & 9191892 & 0,516 & 0,509 & 0,594 & 0,368 & 0,481 \\
\hline 2. & $\begin{array}{l}\text { Open Land (Shrub land) in } \\
\text { ecotourism area }\end{array}$ & 701924 & 9191725 & 0,482 & 0,433 & 0,677 & 0,571 & 0,632 \\
\hline 3. & $\begin{array}{l}\text { Pond area of the } \\
\text { ecotourism }\end{array}$ & 702494 & 919578 & 0,359 & 0,312 & 0,397 & 0,217 & 0,314 \\
\hline 4. & Estuary of the ecotourism & 703585 & 9192102 & 0,161 & 0,195 & 0,125 & 0,162 & 0,111 \\
\hline 5. & $\begin{array}{l}\text { Mangrove Forest } \\
\text { Measurement Point }\end{array}$ & 703614 & 9192005 & 0,187 & 0,424 & 0,478 & 0,793 & 0,879 \\
\hline
\end{tabular}


The spatial changes on mangrove area in Surabaya from 1996-2016 were related to the trend of temperature change. The temperature tends to be high in an open land or in a narrowing mangrove area. Such changes can be seen in Table 6:

Table 6

Trend of Temperature Changes in Mangrove Forest Area in Surabaya

\begin{tabular}{|c|c|c|c|c|c|c|c|c|}
\hline \multirow[t]{2}{*}{ No } & \multirow[t]{2}{*}{ Location } & \multicolumn{2}{|c|}{ Coordinate Point } & \multicolumn{5}{|c|}{ Surface Temperature Change } \\
\hline & & $x$ & $\mathbf{Y}$ & 1996 & 2001 & 2006 & 2011 & 2016 \\
\hline 1. & $\begin{array}{l}\text { The main parking area of } \\
\text { Mangrove Ecotourism in } \\
\text { Wonorejo }\end{array}$ & 701500 & 9191892 & 24,3 & 29,6 & 27,7 & 27,5 & 30,3 \\
\hline 2. & $\begin{array}{l}\text { Open Land (Shrub land) in } \\
\text { ecotourism area }\end{array}$ & 701924 & 9191725 & 24,3 & 29,5 & 27,3 & 27,4 & 28,7 \\
\hline 3. & Pond area of the ecotourism & 702494 & 919578 & 23,4 & 28,1 & 28,4 & 28,5 & 31,5 \\
\hline 4. & Estuary of the ecotourism & 703585 & 9192102 & 23,4 & 27,1 & 27,4 & 27,6 & 27,4 \\
\hline 5. & $\begin{array}{l}\text { Mangrove Forest } \\
\text { Measurement Point }\end{array}$ & 703614 & 9192005 & 23,8 & 27,4 & 26,1 & 26,6 & 27,9 \\
\hline
\end{tabular}

\section{Ability of Mangroves to absorb Carbon Dioxide $\left(\mathrm{CO}_{2}\right)$ from the Air in Surabaya}

Based on the identification of $\mathrm{CO}_{2}$ distribution in the air of Surabaya, the 40 samples taken were different in characters depended on the land use or land coverage. The lowest $\mathrm{CO}_{2}$ distribution was $352 \mathrm{ppm}$ and the highest was $587 \mathrm{ppm}$. The identification results of $\mathrm{CO}_{2}$ distribution in Surabaya are presented in Table 7. 
Table 7

CO2 content distribution in the Air of Surabaya based on the Survey Results

\begin{tabular}{|llllll|}
\hline No & Classification & $\begin{array}{l}\text { CO2 in } \\
\text { the Air }\end{array}$ & $\begin{array}{l}\text { Number of } \\
\text { Distribution }\end{array}$ & $\begin{array}{l}\text { Percentage } \\
(\%)\end{array}$ & Land Use \\
\hline 1 & $\begin{array}{l}\text { Extremely } \\
\text { Low }\end{array}$ & $\begin{array}{l}352- \\
394\end{array}$ & 1 & 2.5 & Estuary \\
\hline 2 & Low & $\begin{array}{l}395- \\
446\end{array}$ & 0 & 0 & - \\
\hline 3 & Moderate & $\begin{array}{l}447- \\
493\end{array}$ & 1 & 2.5 & Estuary, Mangrove, \\
\hline 4 & High & $\begin{array}{l}494- \\
540\end{array}$ & 11 & 27.5 & $\begin{array}{l}\text { Pond, Industry, Cemetery, Zoo, Golf } \\
\text { Course, Campus, Residential area }\end{array}$ \\
\hline 5 & $\begin{array}{l}\text { Extremely } \\
\text { High }\end{array}$ & $\begin{array}{l}541- \\
587\end{array}$ & 27 & 67.5 & $\begin{array}{l}\text { Road, Industry, Residential area, } \\
\text { Commercial area, }\end{array}$ \\
\hline & \begin{tabular}{l} 
Total \\
\hline
\end{tabular} & 40 & 100 & \\
\hline
\end{tabular}

Table 8

Definitions Of Graph CO2 Content Changes In Surabaya

\begin{tabular}{|llllllll|}
\hline NO & LAND USE & NO & LAND USE & NO & LAND USE & NO & LAND USE \\
\hline 1 & Estuary 1 & 11 & Golf Course & 21 & Container Port & 31 & Fishing pond \\
\hline 2 & Estuary 2 & 12 & Housing & 22 & $\begin{array}{l}\text { Mangrove Port of } \\
\text { Wonorejo }\end{array}$ & 32 & Station \\
\hline 3 & Mangrove & 13 & Industry & 23 & Residential Area & 33 & Highway \\
\hline 4 & Mangrove & 14 & JISoekarno & 24 & Commerce & 34 & Residential area \\
\hline 5 & Pond & 15 & Factory & 25 & Factory & 35 & Residential area \\
\hline 6 & Riau & 16 & Industry & 26 & Industry & 36 & Residential area \\
\hline 7 & Factory & 17 & Factory & 27 & Office complex & 37 & Shrub land \\
\hline 8 & Cemetery & 18 & Housing & 28 & Factory & 38 & Housing \\
\hline 9 & ITS & 19 & Container & 29 & Housing & 39 & $\begin{array}{l}\text { Commercial } \\
\text { Roads }\end{array}$ \\
& Campus & & & & & Kenjeran Housing \\
\hline 10 & Zoo & 20 & $\begin{array}{l}\text { Residential } \\
\text { area }\end{array}$ & 30 & Office complex & 40 & $\begin{array}{l}\text { Gegana } \\
\text { Detachment }\end{array}$ \\
\hline
\end{tabular}

The data collected from the survey shown in Table 7 showed the $\mathrm{CO}_{2}$ content in the air of Surabaya was distributed in the categories of high and extremely high, i.e. $27.5 \%$ and $67.5 \%$, respectively. There was 1 
sample point in moderate and low categories with a percentage of $2.5 \%$. The $\mathrm{CO}_{2}$ content in Surabaya was categorized as extremely high. It meant that Surabaya has already experienced a glasshouse effect that could be seen from the correlation between the temperature values and the $\mathrm{CO}_{2}$ content in the air. The map of $\mathrm{CO}_{2}$ spatial distribution in Surabaya Fig. 5.

The condition of $\mathrm{CO}_{2}$ content is obtained on the land use as an estuary and the object with water characteristics, while the highest $\mathrm{CO}_{2}$ content was generally obtained in developed area with the land uses of residential area, industrial area, roads, dry ponds, cemetery, and stations.

The above figure showed that, generally, the high temperature and high $\mathrm{CO}_{2}$ content in Surabaya were found in developed areas. Usually, the $\mathrm{CO}_{2}$ content is low in vegetation cover and waters. Even though the $\mathrm{CO}_{2}$ content in mangrove area was categorized as moderate, but it was still lower than those in residential areas or other developed areas. It can be proven by a comparison of $\mathrm{CO}_{2}$ content in mangrove forests and developed areas (Fig. 6 and Tabel 8).

\section{Discussion}

Based on the results of interpretation and survey on mangrove forest area, there is a correlation between land use changes and the increased surface temperature. The five sample points in the area of Wonorejo Mangrove Forest showed that there was a significant spatial effect of mangrove area conversion into developed area or open land. Such significant effect can be seen from the parameter of surface temperature changes observed based on Landsat images from 1996-2016 and the results of survey used to validate the temperature. Stated that there is a positive correlation between the increase of $\mathrm{CO}_{2}$ emission and the global temperature [12].

The dynamics of mangrove area had unique stages. The change was initiated with the land use conversion from mangrove area into ponds. Such conversion affected the temperature since the $\mathrm{CO}_{2}$ which was initially absorbed by the mangrove can increase openly after the conversion.

The ponds located in the mangrove area had been explicitly owned by the society as private properties. Therefore, the people can change or sell their rights of ownership to other parties including housing developers. It was proven by the interview results with the society who explained about the ownership of the ponds.

Mangrove forests have an essential role for the city of Surabaya. Besides as a conservation area against erosion and sea abrasion, it also functions as a protector from global warming. Mangrove forests have a good ability to reduce the glasshouse gas, i.e. $\mathrm{CO}_{2}$ [13]. They are significant, global contributors for the low carbon cycle in the sea latitude, and glasshouse emission caused by tropical deforestation [8].

The increasing concentration of carbon dioxide ( $\mathrm{CO} 2)$ has a significant influence on plants. The selection of the type of plant determines whether or not it would endure and be able to adapt with the climate 
change [14]. It is in line with the selection of the type of mangrove to be developed that should consider its high ability to absorb $\mathrm{CO} 2$ and to endure various kinds of sedimentation. Each type of mangrove is sensitive to the sedimentary condition and temperature rise [13]. A research conducted by [15] entitled "Estimation of Carbon Stock in Rhizophora Stylosa Tress at Camplong Beach, Sampang - Madura" concluded that the carbon content in the high tide zone was higher than that in the low tide zone.

The spatial changes found in the mangrove forest area in Surabaya from 1996-2016 were related to the trend of temperature changes. Therefore, green areas should be included in spatial planning in order to control the global warming effects in Indonesia [16].

The model of open green space management in reducing CO2 should not only consider the green space in coastal areas but also along the commercial roads, railways, around the industrial area, residential area, and so on [17]. Since urban heat islands appeared frequently in areas with many activities, reforestation using reflective materials has positive impacts on global warming and urban heat island mitigation [18].

The mangrove forests located along the east coast of Surabaya should be maintained as protection areas. Such mangrove forest management is a form of adaptation to and mitigation of global warming [19].

\section{Conclusion}

There were changes on the mangrove area and temperature within two decades from 1996-2016. The mangrove area became larger in 2016. It was due to the distribution of mangrove to coastal areas because of sedimentation expansion. The temperature became higher due to the conversions of mangrove forests into ponds and developed areas such as airport, residential area, and industrial expansions. The $\mathrm{CO}_{2}$ content on waters, mangrove, and developed areas have different characteristics. The highest temperatures were found in residential and industrial areas and the lowest temperatures were found in the estuaries.

\section{Declarations}

\section{Acknowledgments}

The authors wish to thank the State University Of Malang, Indonesia and University Hamzanwadi, Selong, Indonesia, to provide the valuable resources to carry out this study.

\section{Authors' contributions}

All the authors have contributed to the structure, content, and writing of the paper. All authors read and approved the final manuscript. 


\section{Funding}

The authors confirm that no funding was received to carry out this study.

\section{Availability of data and materials}

All data generated or analysed during this study are included within the article.

\section{Competing interests}

The authors declare that they have no competing interests.

\section{Author details}

Sumarmi, Lecturer Geography Education Department, Faculty of Social Sciences, UniversitasNegeri Malang (State University of Malang), Indonesia.sumarmi.fis@um.ac.id. Purwanto, Lecturer Geography Education Department, Faculty of Social Sciences, UniversitasNegeri Malang (State University of Malang), Indonesia.purwanto.fis@um.ac.id.TutiMutia, Lecturer Geography Education Department, Faculty of Social Science and Economic, University Hamzanwadi (STKIP Hamzanwadi), Selong, Indonesia.mutiatia92@yahoo.co.id

\section{Refrences}

1. [1] Bryan S, Dionysius. Analisarelasiperubahantutupanlahandansuhupermukaantanah di kotasurabayamenggunakancitrasatelitmultispektraltahun 1994 - 2012. Jurnalteknikpomits; 2013, Vol. 2: 1

2. [2] Bruno C, Walsh P.M, Santavicca D, Bracco F.V. High temperature catalytic combustion of CO-02-N2, Ar, He, CO2-H20 mixtures of platinum. Int. J. Heat Mass Transf:;1983, 26: 1109-1120

3. [3] Daniel. The Plant Cell Wall-Decomposing Machinery Underlies the Functional Diversity of Forest Fungi. Washington DC: American Association for the Advancement of Science;1983

4. [4] Hilmi E. Model pendugakandungankarbonpadapohonkelompokjenisRhizophora spp. danBruguiera spp. dalamtegakanhutan mangrove (Studikasus di Indragiri Hilir Riau).PascaSarjanalnstitutPertanian Bogor; 2003

5. [5] Donato D.C, Kauffman J.B, Mackenzie R.A, Ainsworth A, Pfleeger A.Z. Whole-island carbon stocks in the tropical Pacific: Implications for mangrove conservation and upland restoration. J. Environ. Manage; 2011, 97: 89-96.

6. [6] Donatto. Mangroves among the most carbon-rich forests in the tropics. Jurnal Natural Science,2011 
7. [7] Jungmeier G, Resch G, Spitzer J. Environmental burdens over the entire life cycle of a biomass CHP plant.Biomass Bioenergy; 1998, 15: 311-323.

8. [8] Alongi D.M, Mukhopadhyay S.K. Contribution of mangroves to coastal carbon cycling in low latitude seas.Agric. For. Meteorol.; 2015, 213: 266-272

9. [9] Geller G.N, Halpin P.N, Helmuth B, Hestir E.L, Skidmore A, Abrams M.J, Aguirre N, Blair M, Botha E, Colloff M. Remote Sensing for Biodiversity, in: The GEO Handbook on Biodiversity Observation Networks. Springer; 2017

10. [10] Lillesand T.M, Kiefer R.W, Chipman J.W. Remote Sensing and Image Interpretation. Fifth Edition. New York: John Wiley \& Sons, Inc; 2004

11. [11] Bolstad P. GIS fundamentals: a first text on geographic information systems, 5th edition. ed. XanEdu, Acton, MA White Bear Lake, Minnesota; 2016

12. [12] Kristoufek L. Has global warming modified the relationship between sunspot numbers and global temperatures?.Phys. Stat. Mech. Its Appl; 2017, 468: 351-358.

13. [13] Leopold A, Marchand C, Deborde J, Allenbach M. Temporal variability of $\mathrm{CO} 2$ fluxes at the sediment-air interface in mangroves (New Caledonia). Sci. Total Environ; 2015, 502: 617-626

14. [14] Prasad P.V.V, Thomas J.M.G, Narayanan S. Global Warming Effects, in: Encyclopedia of Applied Plant Sciences (Second Edition). Academic Press, Oxford; 2017

15. [15] Imiliyana A, Muryono M, Purnobasuki $H$.

EstimasiStokKarbonpadaTegakanPohonRhizophorastylosa di PantaiCamplong, SampangMadura.Surabaya:

FakultasMatematikadanIImuPengetahuanAlamInstitutTeknologiSepuluhNopember,2014, 8:1-13.

16. [16] Sumarmi.AntisipasiDampakPemanasan Global di Indonesia. Jurnal MIPA danPembelajaran,2007

17. [17] Sumarmi.Model pengelolaanruangterbukahijau (RTH) dijalanrayauntukmengurangisuhuudaradanemisi CO2 di kota Malang; 2012

18. [18] Yumino S, Uchida T, Sasaki K, Kobayashi H, Mochida A.Total assessment for various environmentally conscious techniques from three perspectives: Mitigation of global warming, mitigation of UHls, and adaptation to urban warming.Sustain. Cities Soc.;2015, 19:236-249.

19. [19] Seifu, WondimagegnTesfaye Lemma. Climate change perception and choice of adaptation strategies.International Journal of Climate Change Strategies and Management,2016, 8: 253- 270.

20. [20] Rachmawati, Ditha. PotensiEstimasiKarbonTersimpanPadaVegetasi Mangrove Di Wilayah PesisirMuaraGembongKabupatenBekasi. Omni-Akuatika; 2014

\section{Figures}




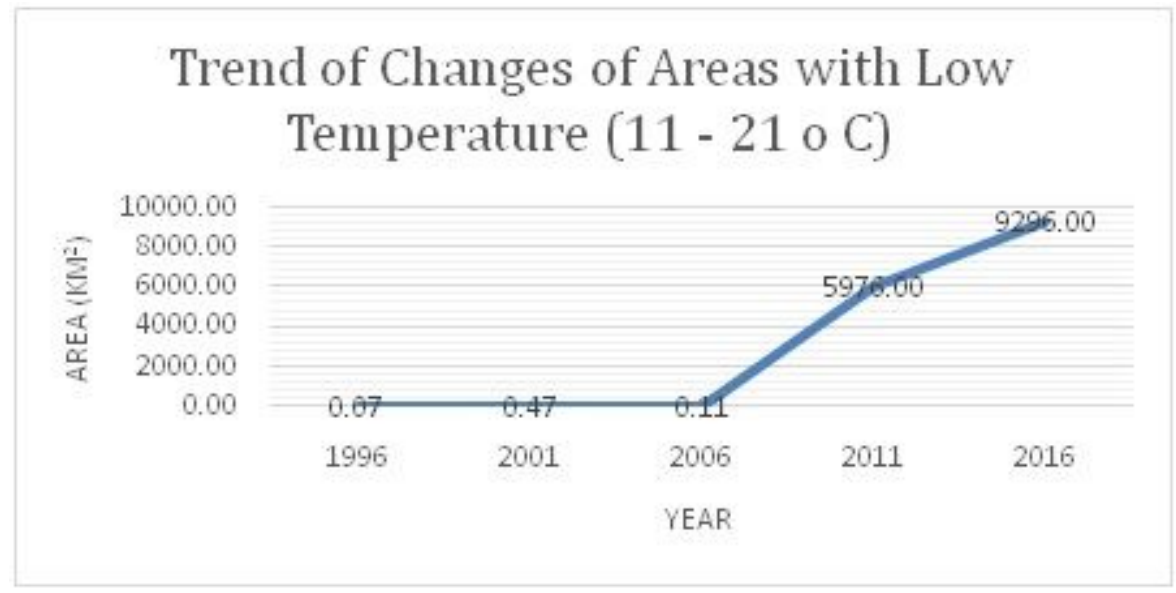

\section{Figure 1}

Trend of Changes in Areas with Low Temperature in Surabaya from 1996-2016

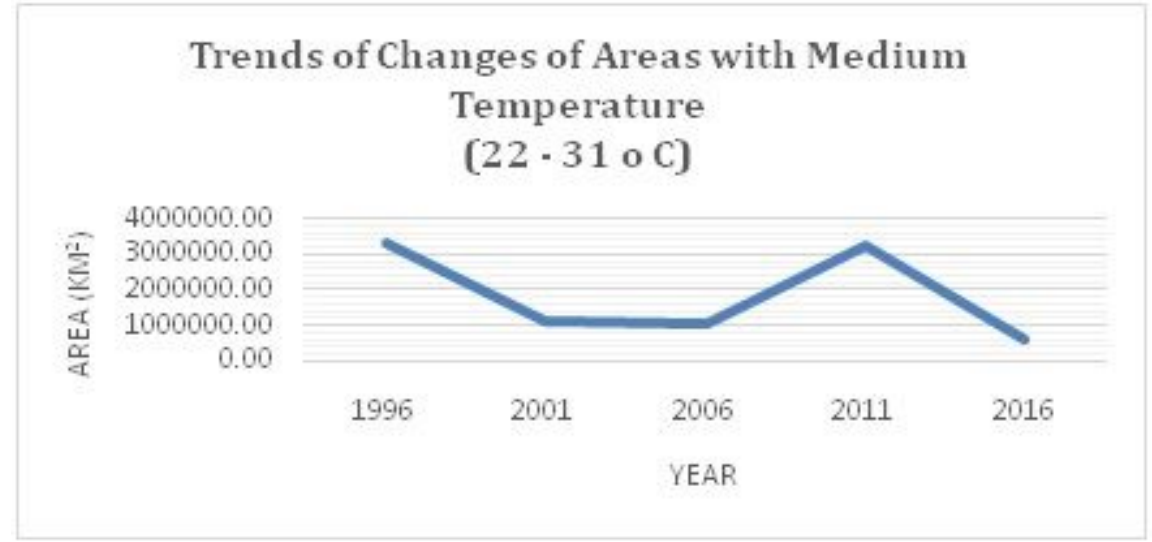

\section{Figure 2}

Trends of Changes of Areas with Moderate Temperature in Surabaya from 1996-2016

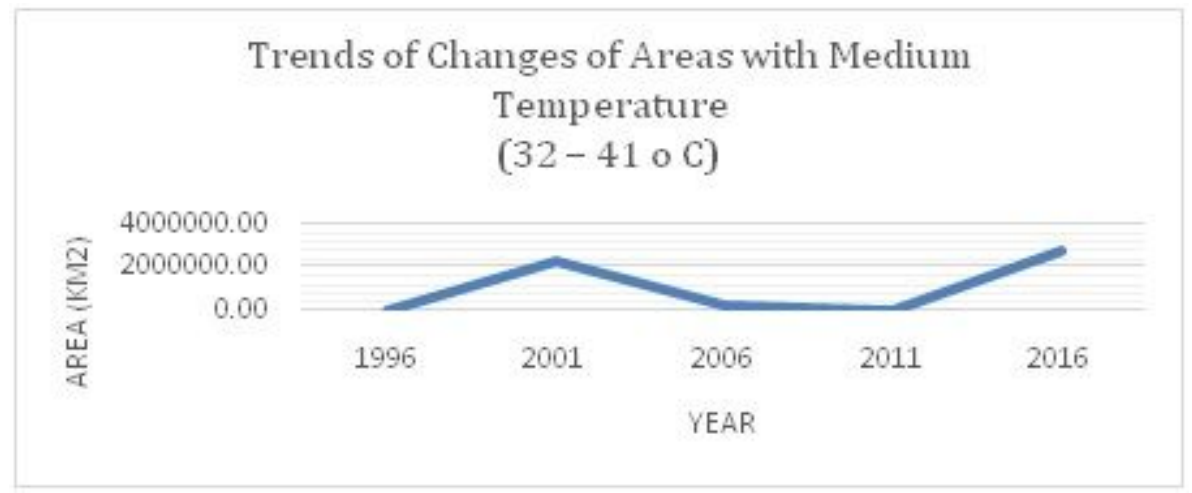

\section{Figure 3}

Graph of Trend of Changes of Areas with High Temperature in Surabaya from 1996-2016 


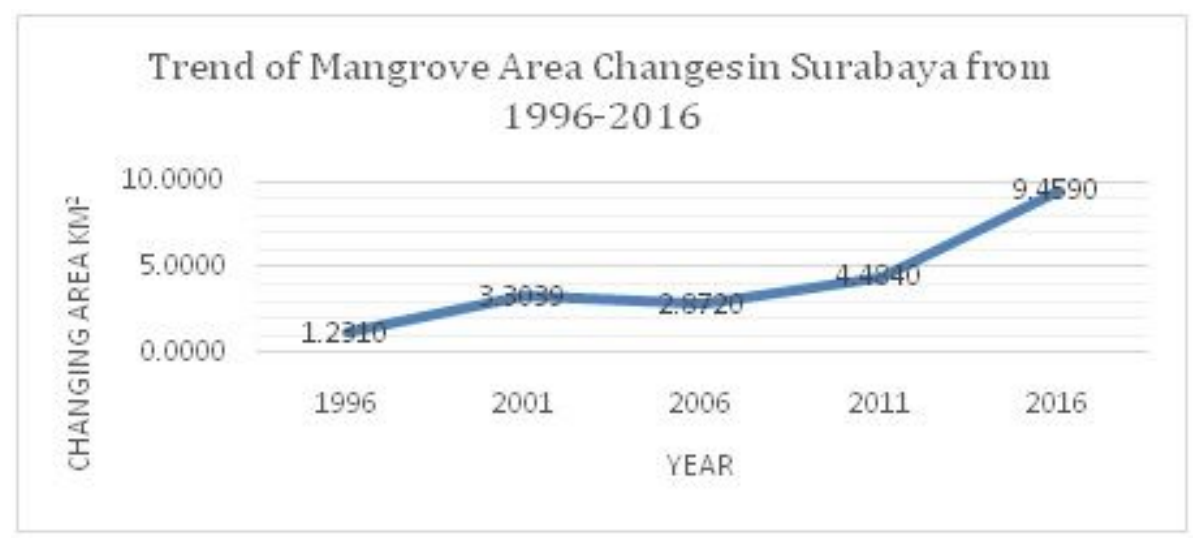

\section{Figure 4}

Graph of Mangrove Area Changes in Surabaya from 1996-2016

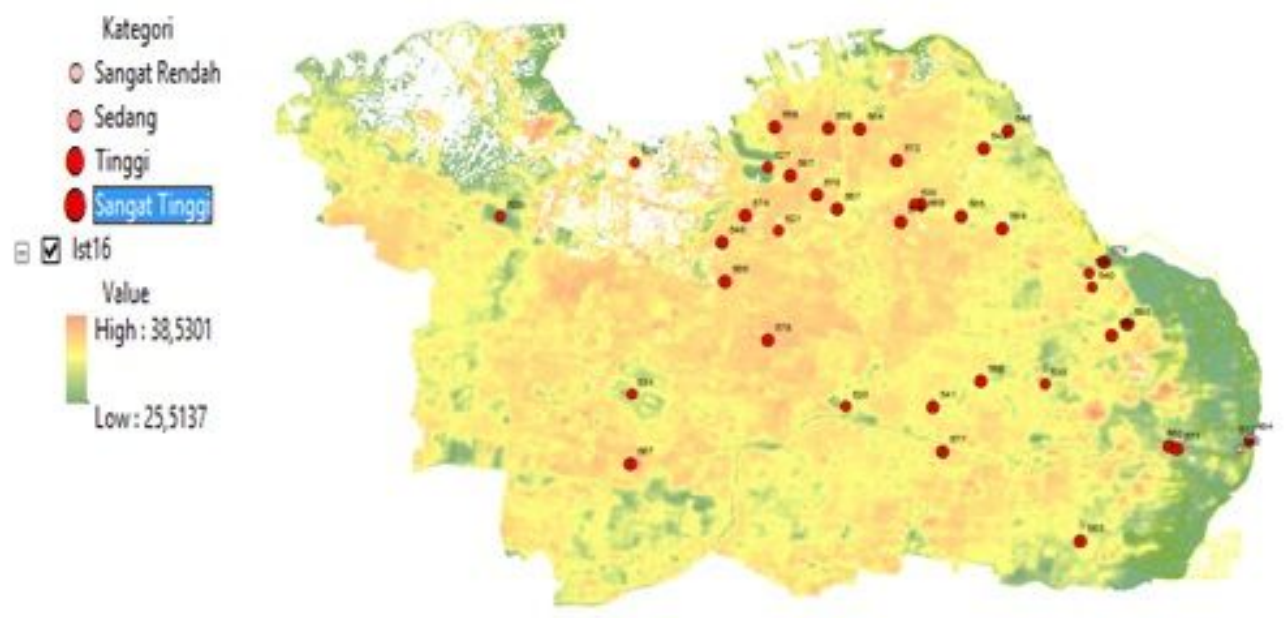

\section{Figure 5}

Map of CO2 Content Distribution in Surabaya in 2016 compared with the Surface Temperature

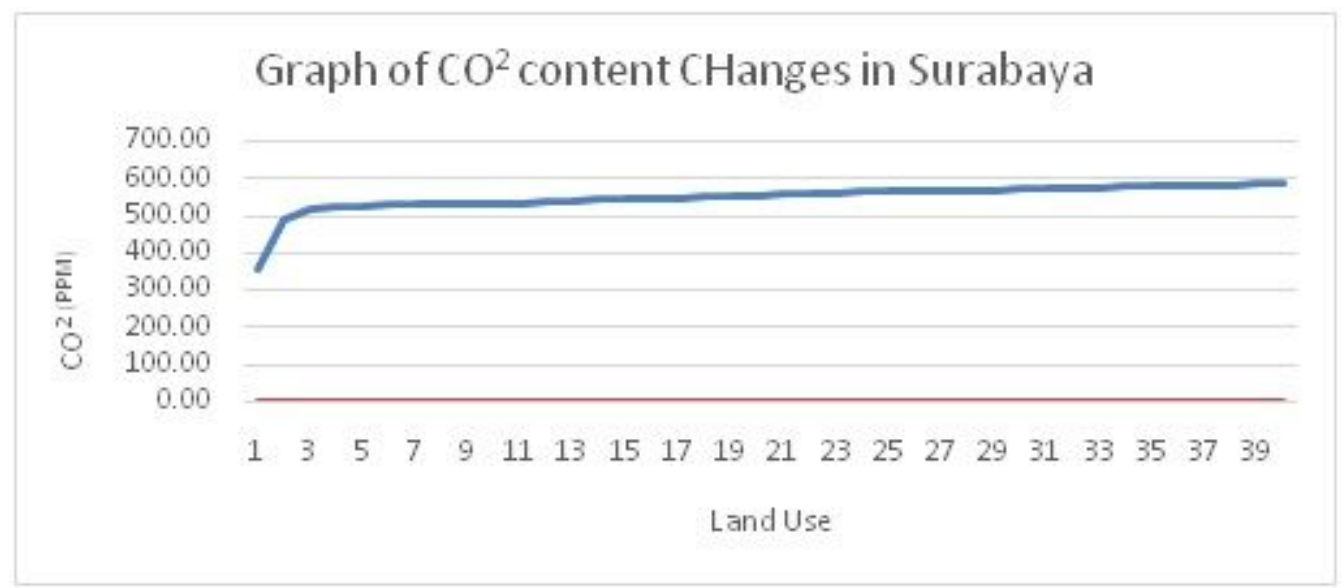

Figure 6

Graph of CO2 Content Changes In Surabaya 
Page 18/18 